at other times it usually takes refuge in an untenanted old shell of the common whelk (Buccinum undatum), where it is secure from the gobies and other fishes in the tank, and where it watches-as one can see its fellows do so at any time on the sea-coast in the middle of a rock-pool-expecting the return of the tide and prepared to adapt itself thereto. In " A Year at the Shore," pp. 215-16, Mr. P. H. Gosse, F.R.S., mentions, on the authority of Mr. Ross, of Topsham, the case of a blenny which for five months proved " a regular and correct tide-indicator," spending a portion of its time on the rock-work, and going back to the tank at the time of the return of the tide.

I quite agree with Mr. Arthur R. Hunt's idea that it would be a great gain if we could copy Nature a little closer, and have "working-models of the sea in some of our new aquariums."

Birmingham, July 22

W. R. HUGHES

\section{Artificial Earthquakes}

PROF. MILNE's experiments with artificial earthquakes in Japan, noticed in NATURE of June 4 (p. I I4), show that the vertical free surface-wave had the quickest rate of transit, and this was taken to account for the preliminary tremors of an earthquake. The normal wave travelled with a less velocity, and the transverse wave slowest of all. In the earthquakes which occur here from time to time there are generally, if not always, two distinct shocks felt, and it is possible that the second is the transverse wave following on after the swifter normal vibration. I have not heard that there are any seismographs in the Punjab, and in the alarm of the moment it is not easy to notice the direction of the motion without apparatus fortunately our earthquakes do not leave any automatic record in the shape of fissures or fallen buildings. But Prof. Milne's experimental results are curiously confirmed by observations in Kashmir during the earthquakes of this month, which do not appear yet to have quite subsided. The Kashmir correspondent of the Lahore Civil and Military Gazette of to-day's date writes as follows:- "The more severe shocks seemed to be followed by others in a different direction, like cross waves. I noticed this in a boat which quivered all over during a severe earthquake, but rolled somewhat afterwards."

Government College, Lahore, June 29

\section{The Recent Earthquake in Switzerland}

THE following is a table of events of the earthquake in Switzerland of June 20 last, compiled from numerous and interesting observations of the phenomenon, obligingly forwarded to me from all parts of the country.

The earthquake consisted of a series of shocks:-

r. Preparatory Shocks. - Very weak and ill-defined from midnight to 3 a.m. ; at Neuchâtel and Chaud-de-Fonds.

2. Great Shock - At 5.16 on the morning of June 20 ; at the centre of the earthquake.

3. Consecutive Shocks. - At 7.26 a.m. June 22 at Neuchâtel at 8.30 a.m. of June 22 at Yverdun, Payerne, Estavayer, Concise, Boudry, Neuchâtel; at I I a.m. of June 23 at St. Imier ; at 2.30 p.m. of June 23 at Neuchâtel; at 9.20 a.m. of June 24 at Yverdun (?)

The great shock had its centre near Y Yonand and the central nrea may be defined by the triangle formed by Yvcrdun, Neuchâtel and Payerne. The shock was strong enough to alarm the inhabitants, to displace some articles of furniture and even to throw down a chimney at Payerne. I assign to the shock the strength of number 6 on the scale of intensity, of which number ro would stand for the highest degree. The shock was felt more feebly in a vast territory extending as far at least as Geneva, Le Brassus, Le Locle, Bâle, Glaris, Thun, Saxon: that is, it traversed the whole plain of Western Switzerland from the Jura Alps. A subterranean noise was heard very distinctly in the whole central area and even a little beyond it.

The shock had very markedly the character of successive oscillations, horizontal or vertical, their direction differing according to the locality. Such is, indeed, the usual type of earthquakes, as has been shown by the study of them with registering instruments, and it is interesting to notice that the various observations of the earthquake of June 20 all perfectly concur in ascribing to it. this character. Morges

\section{THE PITCHER PLANT}

THE variety of the Pitcher Plant (Sarracenia variolaris) found in North America is carnivorous, being a feeder on various animal substances.

Mrs. Mary Treat, an American naturalist, made, a few years ago, several experiments upon the plants of this species to be found in Florida; and to the labours of this lady the writer has been indebted, in some measure, in the preparation of this paper.

The Sarracenia derives its name of "Pitcher Plant" from the fact of its possessing the following curious characteristics. The median nerve is prolonged beyond the leaves in the manner of a tendril, and terminates in a species of cup or urn. This cup is ordinarily three or four inches in depth, and one to one and a half inches in width. The orifice of the cup is covered with a lid, which opens and shuts at certain periods. At sunrise the cup is found filled with sweet, limpid water, at which time the lid is down. In the course of the day the lid opens, when nearly half the water is evaporated; but during the night this loss is made up, and the next morning the cup is again quite full, and the lid is shut.

About the middle of March the plants put forth their leaves, which are from six to twelve inches long, hollow, and shaped something like a trumpet, whilst the aperture at the apex is formed almost precisely in the same manner as those of the plants previously described. A broad wing extends along one side of the leaf, from the base to the opening at the top; this wing is bound, or edged with a purple cord, which extends likewise around the cup. This cord secretes a sweet fluid, and not only flying insects, but those also that crawl upon the ground, are attracted by it to the plants. Ants, especially, are very fond of this fluid, so that a line of aphides, extending from the base to the summit of a leaf, may frequently be observed slowly advancing towards the orifice of the cup, down which they disappear, never to return. Flying insects of every kind are equally drawn to the plant; and directly they taste the fluid they act very curiously. After feeding upon the secretions for two or three minutes they become quite stupid, unsteady on their feet, and whilst trying to pass their legs over their wings to clear them, they fall down.

It is of no use to liberate any of the smaller insects, every fly, removed from the leaf upon which it had been feeding, returned immediately it was at liberty to do so, and walked down the fatal cup as though drawn to it by a species of irresistible fascination.

It is not alone that flies and other small insects are overpowered by the fluid which exudes from the cord in question. Even large insects succumb to it, although of course not so quickly. Mrs. Treat says:- "A large cockroach was feeding on the secretion of a fresh leaf, which had caught but little or no prey. After feeding a short time the insect went down the tube so tight that I could not dislodge it, even when turning the leaf upside down and knocking it quite hard. It was late in the evening when I observed it enter; the next morning I cut the tube open; the cockroach was still alive, but it was covered with a secretion produced from the inner surface of the tube, and its legs fell off as I extricated it. From all appearance the terrible Sarracenia was eating its victim alive. And yet, perhaps, I should not say 'terrible,' for the plant seems to supply its victims with a Lethe-like draught before devouring them."

If only a few insects alight upon a leaf no unpleasant smell is perceptible during, or after, the process of digestion; but if a large number of them be caught, which is commonly the case, a most offensive odour emanates from the cup, although the putrid matter does not appear to injure in any manner the inner surface of the tube food, even in this condition, being readily absorbed, and going to nourish the plant. In fact, it would seem tha 